\title{
Influence of Combinations of Some Permeable Cryoprotectants with Chicken and Duck Egg Yolks on Freezability and DNA Integrity of Buffalo Spermatozoa
}

\author{
Rawash, Z.M. ${ }^{1}$; Amal Z. Leil ${ }^{2}$ Abeer M. Anwer ${ }^{3}$, and El-Badry, D.A. ${ }^{1^{*}}$ \\ ${ }^{1}$ Dept. Artificial Insemination and Embryo Transfer, Animal Reproduction Research Institute, Agriculture \\ Research Center. Giza, Egypt. \\ ${ }^{2}$ Dept. Field Investigations' Animal Reproduction Research Institute, Agriculture Research Center. Giza, Egypt. \\ ${ }^{3}$ Immunology and Immunopharmacology Unit, Animal Reproduction Research Institute, Agriculture Research \\ Center. Giza, Egypt. \\ *Corresponding Author, Diya'udin Abdel Moemen El-Badry, E-mail: diyabadry@ hotmail.com
}

\begin{abstract}
The present study aimed to investigate the cryoprotective effect of different combinations of glycerol (G), dimethyl sulphoxide (DMSO) and dimethylformamide (DMF) with chicken egg yolk (CEY) and duck egg yolk (DEY) on freezability of buffalo spermatozoa. Semen samples were collected from 4 buffalo bulls and diluted with Tris-based extender supplemented with 7\% (V/V) cryoprotectant including G, DMSO, DMF or a mixture of $3.5 \% \mathrm{G}+3.5 \% \mathrm{DMSO}, 3.5 \% \mathrm{G}+3.5 \% \mathrm{DMF}$ and $3.5 \%$ DMSO + 3.5\% DMF. All the fore-mentioned aliquots were divided into two equal portions; one is supplemented with chicken's egg yolk (CEY) and the other with duck's egg yolk (DEY). Post-thawing sperm motility, viability and acrosomal, plasmatic membrane and DNA integrities were assessed. The results clearly indicated that adding a mixture of $3.5 \% \mathrm{G}+$ $3.5 \%$ DMSO with DEY to Tris extender significantly improved $(p<0.01)$ post-thawing sperm motility, viability index and percentage of spermatozoa with intact acrosomes, plasma membrane and DNA $(58.33 \% \pm 1.66 \%, \quad 173.33 \pm 5.46, \quad 69.00 \pm 1.58 \%, \quad 65.00 \pm 1.15 \% \quad$ and $96.91 \pm 0.13 \%$, respectively) compared with the use of $7 \% \mathrm{G}$ and CEY $(51.50 \pm 1.44 \%, 146.25 \pm 6.49,61.00 \pm 2.30,58.00 \pm 1.15 \%$ and $91.40 \pm 0.17$, respectively). In conclusion, motility and functional integrity of cryopreserved buffalo spermatozoa could be enhanced by using Tris extender containing a mixture of $3.5 \%$ glycerol $+3.5 \%$ DMSO with duck's egg yolk.
\end{abstract}

Keywords: Buffalo, cryoprotectants, duck egg yolk, freezing, glycerol, spermatozoa.

\section{INTRODUCTION}

Semen cryopreservation offers many advantages to the livestock industry, particularly in conjunction with allowing the widespread dissemination of valuable genetic material using artificial insemination (Bucak and Uysal, 2008). The success of an AI program depends on the proper management of semen collection, storage and use

\section{Original Article:}

DOI: HTTPS://DX.DOI.ORG/10.21608/J

AVS.2020.98371

Received :11 May, 2020.

Accepted:13 June, 2020.

Published in July, 2020.

This is an open access article under the term of the Creative Commons Attribution 4.0 (CC-BY) International License . To view a copy of this license, visi http://creativecommons.org/licenses/by/4.0/

J. Appl. Vet. Sci., 5(3 ): 49- 56.
(Leboeuf $\boldsymbol{e t}$ al., 2000). There are many factors, which play a role in the successful cryopreservation of semen such as type of extender, the concentration of cryoprotectant, freezing methods, equilibration times and the temperatures used (Purdy, 2006). The cryopreservation process is known to cause damage to sperm cell morphology, resulting in a loss of approximately $40-50 \%$ of viable sperm and leading to a lower fertility rate (Lei et al., 2007). Consequently, 
cryoprotectants are added to sperm cryodiluents to protect spermatozoa against this damage (Purdy, 2006). The cryoprotective effect of cryoprotectants against freezing damage acts through several mechanisms, such as lowering the freezing point of intracellular and extracellular water (Royere et al., 1996), penetrating and interacting with cytoplasmic components, as well as forming a protective layer around sperm membranes (García et al., 2012). Generally, cryoprotectants are classified into two groups, permeable and non-permeable. Permeable cryoprotectants including glycerol, DMSO, acetaldehyde, propylene glycol and ethylene glycol [EG] (Di Santo et al., 2012).

Glycerol is the permeating cryoprotectant most frequently used to freeze semen from different species (Baren et al., 2004; García et al., 2012). However, it has been well documented that glycerol, depending on the concentration used, has chemical and osmotic toxicities to the plasma membrane and metabolism of cryopreserved sperm of mammals, which contributes to the disorganization of the sperm plasma membrane, as well as the reduction in motility and fertilizing ability of sperm (Hammerstedt et al., 1990). Even when using adequate glycerol concentrations, detrimental effects on sperm are not avoided (Moffet et al., 2003; Vidament, 2005). In addition, glycerol at high concentrations can lead to programmed cell death (Wundrich et al., 2006), resulted in a significant increase in the percentage of necrotic spermatozoa (García et al., 2012) and has a deleterious effect on sperm DNA (El-Badry et al., 2014). In buffalo bulls, many authors demonstrated that spermatozoa were better preserved in cryodiluents containing glycerol and DMSO but without EG (Rohilla et al., 2005; ElHarairy et al., 2011; Almadaly et al., 2019).

Egg yolk (depends on containing cholesterol, phospholipids, and low-density lipoprotein) prevents the formation of ice crystals, thus protecting the integrity of sperm plasma membranes against cold shock during the freeze-thaw process (Hu et al., 2010). Chicken EY is the most commonly used EY because of its easy availability (Bathgate $\boldsymbol{e t} \boldsymbol{a l}$. , 2006). However, the extenders containing EYs from other avian species yielded high post-thawing results in buffalo (Akhter $\boldsymbol{e} t$ al., 2017), equine (Webb et al., 2011) bull (Su et al., 2008), and ram sperm (Ali et al., 2013). It is suggested that these improvements are attributed to the differences in the composition of the yolks.

The objective of this study was to assess the effects of permeable cryoprotectants (G, DMSO \& DMF) and egg yolk source (CEY \& DEY) and their combinations on post-thaw parameters of buffalo bull spermatozoa.

\section{MATERIALS AND METHODS}

All experimental procedures were approved by the Institutional Animal Care and Use Committee (IACUC), Cairo University, Faculty of Science.

\section{Preparation of extenders}

Tris-based buffer was prepared according to Reddy et al. (2010), which comprised Tris $33.2 \mathrm{~g} / \mathrm{l}$, citric acid $18.3 \mathrm{~g} / \mathrm{l}$, dextrose $7.8 \mathrm{~g} / \mathrm{l}$ and supplemented with $100 \mathrm{mMol}$ of trehalose (Badr et al., 2010). Antibiotics (gentamycin sulphate $500 \mu \mathrm{g} / \mathrm{mL}$, tylosin tartrate $100 \mu \mathrm{g} / \mathrm{mL}$, lincomycin $\mathrm{HCl} 300 \mu \mathrm{g} / \mathrm{mL}$, and spectinomycin $\mathrm{HCl} 600 \mu \mathrm{g} / \mathrm{mL}$ ) were added to the diluent according to Akhter $\boldsymbol{e t}$ al. (2011). Aliquots of Tris extender were supplemented with $7 \%$ ( $\mathrm{vol} / \mathrm{vol})$ cryoprotectant including glycerol (G), dimethyl sulfoxide (DMSO), dimethylformamide (DMF) or a mixture of $3.5 \% \mathrm{G}+3.5 \% \mathrm{DMSO}, 3.5 \% \mathrm{G}+3.5 \%$ DMF and 3.5\% DMSO + 3.5\% DMF. All the forementioned aliquots were divided into two equal portions; one is supplemented with $20 \%$ chicken's egg yolk (CEY) and the other with $20 \%$ duck's egg yolk (DEY).

\section{Animals and semen collection}

Four healthy buffalo bulls of known fertility, maintained on the experimental farm of Animal Reproduction Research Institute (ARRI), Agriculture Research Center (ARC), were used in the present study. Their age and body weight ranged between 2-3 years and $400-550 \mathrm{Kg}$, respectively. Early in the morning, using a pre-warmed artificial vagina (40-42 ${ }^{\circ} \mathrm{C}$ ), twice a day ejaculates were collected from each bull once per week for five consecutive weeks with a total of 40 ejaculates.

\section{Semen Processing}

Pooled semen samples were diluted with trisbased extender (containing different cryoprotectants and different egg yolks) at $37^{\circ} \mathrm{C}$ in the incubator in an appropriate dilution rate to obtain a final concentration of $50 \times 10^{6}$ sperm cell $/ \mathrm{ml}$. Diluted semen was then cooled slowly to $5^{\circ} \mathrm{C}$ in a cold cabinet for a period of $1.5 \mathrm{~h}$. Semen was loaded in $0.25 \mathrm{ml}$ straws (IMV, France) and placed $4 \mathrm{~cm}$ above liquid nitrogen in the vapour phase in a foam box for 15 minutes before being plunged into the liquid phase (Khalifa, 2001). Straws were stored in liquid nitrogen until thawing (one week after freezing) at $37^{\circ} \mathrm{C}$ in a water bath for 30 sec. Two straws of each treatment $(\mathrm{N}=12)$ and replicate $(\mathrm{N}=5)$ were thawed at $37^{\circ} \mathrm{C}$ in a water bath for $30 \mathrm{sec}$ and pooled for evaluation.

\section{Evaluation of frozen-thawed semen}

Motility estimations were done at hourly intervals for 3 hours. The viability index was calculated according to Milovanov (1962) to be equal to half of 
the post-thaw sperm cells motility in addition to the summation of recorded motility at $1^{\text {st }}, 2^{\text {nd }}$ and $3^{\text {rd }}$ hours post-thawing. The procedure described by Jeyendran et al. (1984) was used to determine the percentage of HOST-positive sperm cells in each semen sample. A $100 \mu \mathrm{l}$ aliquot of each semen sample was mixed in 1.0 $\mathrm{ml}$ of a pre-warmed hypo-osmotic solution $(0.735 \mathrm{~g}$ of sodium citrate dihydrate and $1.351 \mathrm{~g}$ of fructose in 100 $\mathrm{ml}$ of sterile, de-ionized water). The mixture was incubated at $37^{\circ} \mathrm{C}$ for 30 minutes in a $1.5 \mathrm{ml}$ microcentrifuge tube. Following incubation, a small drop of the sample was placed on a clean microscope slide and cover-slipped for examination using phase-contrast microscopy (400X) to evaluate 100 spermatozoa for evidence of swelling and curling changes of the sperm tail. Acrosome integrity was evaluated by a dual staining procedure (Didion et al., 1989). Briefly, spermatozoa were incubated with an equal volume of $0.2 \%$ trypan blue for $10 \mathrm{~min}$ and washed twice (centrifugation at $700 \mathrm{~g}$ for $6 \mathrm{~min}$ ) with saline. Smears were made on glass slides and dried quickly on a warm stage. Slides were stained with $10 \%$ Giemsa stain for $40 \mathrm{~min}$. They were rinsed by distilled water, air-dried, and covered with coverslips. Spermatozoa were classified as acrosome intact [light purple - dark pink acrosome] and damaged/lost acrosome [unstained or blue acrosome].

\section{Sperm cell DNA integrity by Comet assay (Single cell gel electrophoresis)}

The alkaline comet assay for spermatozoa was carried out according to Hughes et al. (1996). Fully frosted glass slides were covered with $100 \mu \mathrm{l}$ of $0.5 \%$ normal melting point agarose (Sigma), a coverslip was added and the agarose was allowed to solidify. The coverslips were removed and $1 \times 10^{5}$ sperm cells in $50 \mu \mathrm{l}$ PBS $(7.2 \mathrm{pH})$ were mixed with $50 \mu \mathrm{l}$ of $1.2 \%$ low melting point agarose and used to form the second layer. The slides with coverslips removed were then placed in lysis buffer for $1 \mathrm{~h}(2.5 \mathrm{M} \mathrm{NaCl}, 100 \mathrm{mM} \mathrm{Na}$ EDTA, $10 \mathrm{mM}$ Tris, $1 \%$ Triton $\mathrm{X}$ at a $\mathrm{pH}$ of 10 ). The slides were then incubated at $37^{\circ} \mathrm{C}$ in $100 \mu \mathrm{l} / \mathrm{ml}$ of proteinase $\mathrm{K}$ in lysis buffer overnight. After draining the proteinase $\mathrm{K}$ solution from the slides, they were placed in a horizontal electrophoresis unit filled with freshly prepared alkaline electrophoresis solution containing $300 \mathrm{mM} \mathrm{NaOH}$ and $1 \mathrm{mM}$ EDTA for 20 min to allow the DNA to denature.

Electrophoresis was performed at room temperature, at $25 \mathrm{~V}(0.714 \mathrm{~V} / \mathrm{cm})$ and $300 \mathrm{~mA}$, obtained by adjusting the buffer level, for $10 \mathrm{~min}$. The slides were then washed with a neutralizing solution of $0.4 \mathrm{M}$ Tris at $\mathrm{pH} 7$ to remove alkali and detergents. After neutralization, the slides were each stained with $50 \mu \mathrm{l}$ of $20 \mu \mathrm{g} / \mathrm{ml}$ ethidium bromide and mounted with a coverslip. A total of 200 sperm cells were examined under a fluorescent microscope (400X). The intensity of the stain in the comet tail region is presumed to be related to the DNA content, and DNA damage is estimated from measurements of the per cent DNA in tail, tail length and tail moment, using an image analysis system (Comet-Score program). Spermatozoa with fragmented DNA (damaged) display increased migration of the DNA from the nucleus towards the anode, while spermatozoa with non-fragmented DNA (undamaged) do not form a "comet" (Fraser, 2004).

\section{Statistical analysis}

One-way analysis of variance and Duncan's multiple range tests were done for the obtained data after the angular transformation of percentages to their corresponding arcsin values (Snedecor and Cochran, 1989). Data were analyzed using SPSS program (version 22.0), and the level of statistical significance was set at $P \leq 0.05$.

\section{RESULTS}

As presented in table 1 , semen samples extended in the extender containing a combination of $\mathrm{G}$ and DMSO with Duck egg yolk has a significantly highest $(p<0.01)$ post-thaw motility and viability index $(58.33 \pm 1.66 \% \& 173.33 \pm 5.46$, respectively). Intermediate significant $(p<0.01)$ values of post-thaw motility and viability indices were shown with diluents containing either $\mathrm{G}$ or DMSO in addition to chicken egg yolk $(52.50 \pm 1.44 \& 146.25 \pm 6.49$ and $47.50 \pm$ $4.33 \% \& 124.58 \pm 10.58$, respectively) or duck egg yolk $(57.50 \pm 4.33 \% \& 196.58 \pm 5.12$ and $50.00 \pm 5$. $77 \%$ \& $135.00 \pm 8.66$, respectively). The significantly lowest $(p<0.01)$ values of post-thaw motility and viability indices were recorded for diluents supplemented with DMF either containing chicken egg yolk $(30.00 \pm 2.88 \% \& 68.33 \pm 5.83$, respectively) or duck egg yolk $(30.00 \pm 5.77 \% \& 73.33 \pm 4.40$, respectively).

Data presented in table 2 showed that the inclusion of a mixture of G + DMSO + duck egg yolk significantly improved the freezability of buffalo spermatozoa in terms of the highest membrane, acrosomal and DNA integrities $(65.00 \pm 1.11 \%, 69.16$ \pm 1.58 and $94.28 \pm 0.15 \%$, respectively) and the lowest DNA damage $(3.08 \pm 0.13 \%, 5.01 \pm 0.10$ pixels and $0.46 \pm 0.00$ for the percentage of DNA in the tail of Comet, tail length and Olive tail moment, respectively, Fig. 1). The significantly lowest ( $p$ $<0.01)$ values of spermatozoa with the membrane, acrosomal and DNA integrities (Fig. 2) were recorded for diluents supplemented with DMF either containing chicken or duck egg yolk. 
Table 1: Effect of different cryoprotectants and egg yolk source on the post-thaw total motility and viability of frozen-thawed buffalo spermatozoa (Mean \pm SEM).

\begin{tabular}{|lccccc|}
\hline \multirow{2}{*}{ CPA } & \multicolumn{5}{c|}{ Post-thaw motility (\%) } \\
\cline { 2 - 5 } & Zero h. & One h. & Two h. & Three h. & Viability index \\
\hline G+CEY & $52.50 \pm 1.44^{\mathrm{ab}}$ & $47.50 \pm 1.44^{\mathrm{abc}}$ & $40.00 \pm 2.88^{\mathrm{abc}}$ & $32.50 \pm 1.44^{\mathrm{bc}}$ & $146.25 \pm 6.49^{\mathrm{bc}}$ \\
\hline DMSO+CEY & $47.50 \pm 4.33^{\mathrm{abc}}$ & $40.00 \pm 5.77^{\mathrm{cd}}$ & $33.3 \pm 1.66^{\mathrm{c}}$ & $27.50 \pm 1.44^{\mathrm{c}}$ & $124.58 \pm 10.85^{\mathrm{d}}$ \\
\hline DMF+CEY & $30.00 \pm 2.88^{\mathrm{e}}$ & $22.50 \pm 4.33^{\mathrm{f}}$ & $18.33 \pm 1.66^{\mathrm{d}}$ & $12.50 \pm 1.44^{\mathrm{d}}$ & $68.33 \pm 5.83^{\mathrm{g}}$ \\
\hline G+DMSO+CEY & $55.00 \pm 2.88^{\mathrm{ab}}$ & $50.00 \pm 2.88^{\mathrm{ab}}$ & $42.50 \pm 1.44^{\mathrm{ab}}$ & $35.00 \pm 2.88^{\mathrm{b}}$ & $155.00 \pm 8.66^{\mathrm{ab}}$ \\
\hline G+DMF+CEY & $45.00 \pm 2.88^{\mathrm{bcd}}$ & $40.83 \pm 2.20^{\mathrm{cd}}$ & $33.33 \pm 1.66^{\mathrm{c}}$ & $27.50 \pm 1.44^{\mathrm{c}}$ & $124.17 \pm 3.63^{\mathrm{d}}$ \\
\hline DMSO+DMF+CEY & $35.00 \pm 4.33^{\mathrm{de}}$ & $30.00 \pm 2.88^{\mathrm{ef}}$ & $25.00 \pm 2.88^{\mathrm{d}}$ & $15.00 \pm 2.88^{\mathrm{d}}$ & $87.50 \pm 4.38^{\mathrm{ef}}$ \\
\hline G+DEY & $57.50 \pm 4.33^{\mathrm{ab}}$ & $52.50 \pm 1.44^{\mathrm{a}}$ & $46.66 \pm 1.66^{\mathrm{a}}$ & $41.66 \pm 1.66^{\mathrm{a}}$ & $169.58 \pm 5.12^{\mathrm{a}}$ \\
\hline DMSO+DEY & $50.00 \pm 5.77^{\mathrm{ab}}$ & $42.50 \pm 1.44^{\mathrm{bc}}$ & $37.50 \pm 1.44^{\mathrm{bc}}$ & $30.00 \pm 2.88^{\mathrm{bc}}$ & $135.00 \pm 8.66^{\mathrm{cd}}$ \\
\hline DMF + DEY & $30.00 \pm 5.77^{\mathrm{e}}$ & $25.00 \pm 2.88^{\mathrm{ef}}$ & $20.00 \pm 2.88^{\mathrm{d}}$ & $13.33 \pm 1.66^{\mathrm{d}}$ & $73.33 \pm 4.40^{\mathrm{fg}}$ \\
\hline G+DMSO+DEY & $58.33 \pm 1.66^{\mathrm{a}}$ & $52.50 \pm 1.44^{\mathrm{a}}$ & $46.66 \pm 1.66^{\mathrm{a}}$ & $45.00 \pm 2.88^{\mathrm{a}}$ & $173.33 \pm 5.46^{\mathrm{a}}$ \\
\hline G+DMF+DEY & $45.00 \pm 0.00^{\mathrm{bcd}}$ & $42.50 \pm 1.44^{\mathrm{bc}}$ & $35.00 \pm 2.88^{\mathrm{c}}$ & $30.00 \pm 2.88^{\mathrm{bc}}$ & $130.00 \pm 1.44^{\mathrm{cd}}$ \\
\hline DMSO+DMF+DEY & $37.50 \pm 4.33^{\mathrm{cde}}$ & $32.50 \pm 1.44^{\mathrm{de}}$ & $25.00 \pm 2.88^{\mathrm{d}}$ & $18.33 \pm 1.66^{\mathrm{d}}$ & $94.58 \pm 3.70^{\mathrm{e}}$ \\
\hline
\end{tabular}

Within columns, means with different alphabetical superscripts $(\mathrm{a}, \mathrm{b}, \mathrm{c})$ are significantly different at least at $p<.05$.

Table 2: Effect of different cryoprotectants and egg yolk source on DNA, membrane and acrosomal integrities of buffalo spermatozoa (Mean \pm SEM).

\begin{tabular}{|c|c|c|c|c|c|c|c|}
\hline \multirow[b]{2}{*}{ CPA } & \multirow[b]{2}{*}{ HOST } & \multirow[b]{2}{*}{$\begin{array}{c}\text { Acrosomal } \\
\text { integrity }\end{array}$} & \multicolumn{5}{|c|}{ DNA Integrity } \\
\hline & & & $\begin{array}{c}\text { Sperm } \\
\text { with non- } \\
\text { fragmente } \\
\text { d DNA }\end{array}$ & $\begin{array}{c}\text { DNA in } \\
\text { the head } \\
\text { of comet } \\
\%\end{array}$ & $\begin{array}{c}\text { DNA in } \\
\text { the tail } \\
\text { of } \\
\text { comet } \%\end{array}$ & $\begin{array}{c}\text { Tail } \\
\text { length } \\
\text { (pixel) }\end{array}$ & $\begin{array}{c}\text { Olive tail } \\
\text { moment }\end{array}$ \\
\hline $\mathrm{G}+\mathrm{CEY}$ & $\begin{array}{l}58.00 \pm \\
1.15^{\mathrm{bc}}\end{array}$ & $\begin{array}{l}61.00 \pm \\
2.30^{\mathrm{bc}}\end{array}$ & $\begin{array}{l}91.40 \pm \\
0.17^{\mathrm{de}}\end{array}$ & $\begin{array}{c}95.83 \pm \\
0.14^{\mathrm{bc}}\end{array}$ & $\begin{array}{l}4.16 \pm \\
0.14^{\mathrm{de}}\end{array}$ & $\begin{array}{l}8.66 \pm \\
0.11^{\mathrm{c}}\end{array}$ & $\begin{array}{l}0.72 \pm \\
0.02^{\mathrm{d}}\end{array}$ \\
\hline DMSO+CEY & $\begin{array}{c}52.00 \pm \\
1.73^{\mathrm{e}}\end{array}$ & $\begin{array}{l}54.33 \pm \\
0.88^{\mathrm{d}}\end{array}$ & $\begin{array}{c}90.80 \pm \\
0.57^{\mathrm{ef}}\end{array}$ & $\begin{array}{r}94.88 \pm \\
0.36^{\mathrm{d}}\end{array}$ & $\begin{array}{l}5.11 \pm \\
0.36^{\mathrm{c}}\end{array}$ & $\begin{array}{l}9.53 \pm \\
0.08^{\mathrm{b}}\end{array}$ & $\begin{array}{l}1.15 \pm \\
0.09^{\mathrm{b}}\end{array}$ \\
\hline $\mathrm{DMF}+\mathrm{CEY}$ & $\begin{array}{l}43.33 \pm \\
1.45^{\mathrm{fg}}\end{array}$ & $\begin{array}{l}40.66 \pm \\
2.02^{f}\end{array}$ & $\begin{array}{l}91.88 \pm \\
0.21^{\mathrm{cd}}\end{array}$ & $\begin{array}{c}96.00 \pm \\
0.28^{\mathrm{b}}\end{array}$ & $\begin{array}{l}4.00 \pm \frac{1}{0} \\
0.28^{\mathrm{e}}\end{array}$ & $\begin{array}{l}7.35 \pm \\
0.57^{\mathrm{d}}\end{array}$ & $\begin{array}{l}0.67 \pm \\
0.00^{\mathrm{de}}\end{array}$ \\
\hline G+DMSO+CEY & $\begin{array}{c}60.33 \pm \\
1.45^{\mathrm{b}}\end{array}$ & $\begin{array}{c}60.90 \pm \\
1.24^{\mathrm{bc}}\end{array}$ & $\begin{array}{c}93.06 \pm \\
0.31^{\mathrm{b}}\end{array}$ & $\begin{array}{r}96.33 \pm \\
0.20^{\mathrm{ab}}\end{array}$ & $\begin{array}{l}3.66 \pm \\
0.20^{\text {ef }}\end{array}$ & $\begin{array}{l}5.91 \pm \\
0.15^{\mathrm{d}}\end{array}$ & $\begin{array}{l}0.56 \pm \\
0.01^{\mathrm{ef}}\end{array}$ \\
\hline $\mathrm{G}+\mathrm{DMF}+\mathrm{CEY}$ & $\begin{array}{l}53.33 \pm \\
0.88^{\mathrm{de}}\end{array}$ & $\begin{array}{l}57.33 \pm \\
1.45^{\mathrm{cd}}\end{array}$ & $\begin{array}{l}92.81 \pm \\
0.18^{\mathrm{bc}}\end{array}$ & $\begin{array}{c}96.15 \pm \\
0.08^{\mathrm{b}}\end{array}$ & $\begin{array}{l}3.85 \pm \\
0.08^{\mathrm{e}}\end{array}$ & $\begin{array}{l}6.40 \pm \\
0.11^{\mathrm{d}}\end{array}$ & $\begin{array}{l}0.73 \pm \\
0.01^{\mathrm{d}}\end{array}$ \\
\hline $\mathrm{DMSO}+\mathrm{DMF}+\mathrm{CEY}$ & $\begin{array}{r}41.00 \pm \\
1.73^{\mathrm{g}}\end{array}$ & $\begin{array}{l}43.33 \pm \\
1.45^{\mathrm{ef}}\end{array}$ & $\begin{array}{c}90.30 \pm \\
0.40^{\mathrm{e}}\end{array}$ & $\begin{array}{r}92.66 \pm \\
0.08^{\mathrm{d}}\end{array}$ & $\begin{array}{l}7.33 \pm \\
0.08^{\mathrm{a}}\end{array}$ & $\begin{array}{r}10.44 \pm \\
0.57^{\mathrm{a}}\end{array}$ & $\begin{array}{l}1.41 \pm \\
0.07^{\mathrm{a}}\end{array}$ \\
\hline$G+D E Y$ & $\begin{array}{c}60.66 \pm \\
2.02^{\mathrm{c}}\end{array}$ & $\begin{array}{c}64.00 \pm \\
1.15^{\mathrm{c}}\end{array}$ & $\begin{array}{c}94.05 \pm \\
0.16^{\mathrm{a}}\end{array}$ & $\begin{array}{l}95.86 \pm \\
0.08^{\mathrm{bc}}\end{array}$ & $\begin{array}{l}4.13+\frac{1}{\mathrm{de}} \\
0.08^{2}\end{array}$ & $\begin{array}{l}7.52 \pm \\
0.11^{\mathrm{d}}\end{array}$ & $\begin{array}{l}0.66 \pm \frac{ \pm}{\mathrm{de}} \\
0.02^{2}\end{array}$ \\
\hline DMSO+ DEY & $\begin{array}{l}53.66 \pm \\
0.88^{\text {cde }}\end{array}$ & $\begin{array}{c}52.66 \pm \\
1.45^{\mathrm{d}} \\
\end{array}$ & $\begin{array}{l}91.40 \pm \\
0.23^{\mathrm{de}} \\
\end{array}$ & $\begin{array}{l}95.33 \pm \\
0.20^{\mathrm{cd}} \\
\end{array}$ & $\begin{array}{l}4.66 \pm \\
0.20^{\mathrm{cd}}\end{array}$ & $\begin{array}{l}8.40 \pm \\
0.23^{\mathrm{c}} \\
\end{array}$ & $\begin{array}{l}0.97 \pm \\
0.01^{\mathrm{c}}\end{array}$ \\
\hline $\mathrm{DMF}+\mathrm{DEY}$ & $\begin{array}{l}46.33 \pm \\
1.45^{\mathrm{f}}\end{array}$ & $\begin{array}{l}46.66 \pm \\
2.02^{\mathrm{e}}\end{array}$ & $\begin{array}{l}92.10 \pm \\
0.51^{\text {bcd }}\end{array}$ & $\begin{array}{l}95.76 \pm \\
0.14^{\mathrm{bc}}\end{array}$ & $\begin{array}{l}4.23 \pm \\
0.14^{\mathrm{de}}\end{array}$ & $\begin{array}{l}7.33 \pm \frac{\mathrm{d}}{\mathrm{d}} \\
0.20^{2}\end{array}$ & $\begin{array}{l}0.58 \pm \\
0.00^{\text {ef }}\end{array}$ \\
\hline G+DMSO+DEY & $\begin{array}{c}65.00 \pm \\
1.15^{\mathrm{a}} \\
\end{array}$ & $\begin{array}{c}69.16 \pm \\
1.58^{\mathrm{a}} \\
\end{array}$ & $\begin{array}{c}94.28 \pm \\
0.15^{\mathrm{a}} \\
\end{array}$ & $\begin{array}{c}96.91 \pm \\
0.13^{\mathrm{a}} \\
\end{array}$ & $\begin{array}{l}3.08 \pm \\
0.13^{\mathrm{f}}\end{array}$ & $\begin{array}{l}5.01 \pm \\
0.10^{\mathrm{f}}\end{array}$ & $\begin{array}{l}0.46 \pm \\
0.00^{f}\end{array}$ \\
\hline G+DMF+DEY & $\begin{array}{l}56.66 \pm \\
0.88^{\text {bcd }}\end{array}$ & $\begin{array}{l}59.33 \pm \\
1.45^{\mathrm{bc}}\end{array}$ & $\begin{array}{c}93.00 \pm \\
0.28^{\mathrm{b}}\end{array}$ & $\begin{array}{l}96.33 \pm \\
0.22^{\mathrm{ab}}\end{array}$ & $\begin{array}{l}3.66 \pm \\
0.22^{\mathrm{ef}}\end{array}$ & $\begin{array}{c}6.08 \pm 0 . \\
13^{\mathrm{d}}\end{array}$ & $\begin{array}{l}0.79 \pm \\
0.05^{\mathrm{d}}\end{array}$ \\
\hline DMSO+DMF+DEY & $\begin{array}{l}43.00 \pm \\
1.73^{\mathrm{fg}}\end{array}$ & $\begin{array}{l}46.00 \pm \\
1.73^{\mathrm{e}}\end{array}$ & $\begin{array}{l}91.33 \pm \\
0.20^{\mathrm{de}}\end{array}$ & $\begin{array}{c}93.30 \pm \\
0.11^{\mathrm{e}}\end{array}$ & $\begin{array}{l}6.70 \pm \\
0.11^{\mathrm{b}}\end{array}$ & $\begin{array}{l}9.66 \pm \pm \\
0.20^{\mathrm{ab}}\end{array}$ & $\begin{array}{l}1.22 \pm \\
0.05^{\mathrm{b}}\end{array}$ \\
\hline
\end{tabular}

Within columns, means with different alphabetical superscripts $(a, b, c)$ are significantly different at least at $p<.05$. 


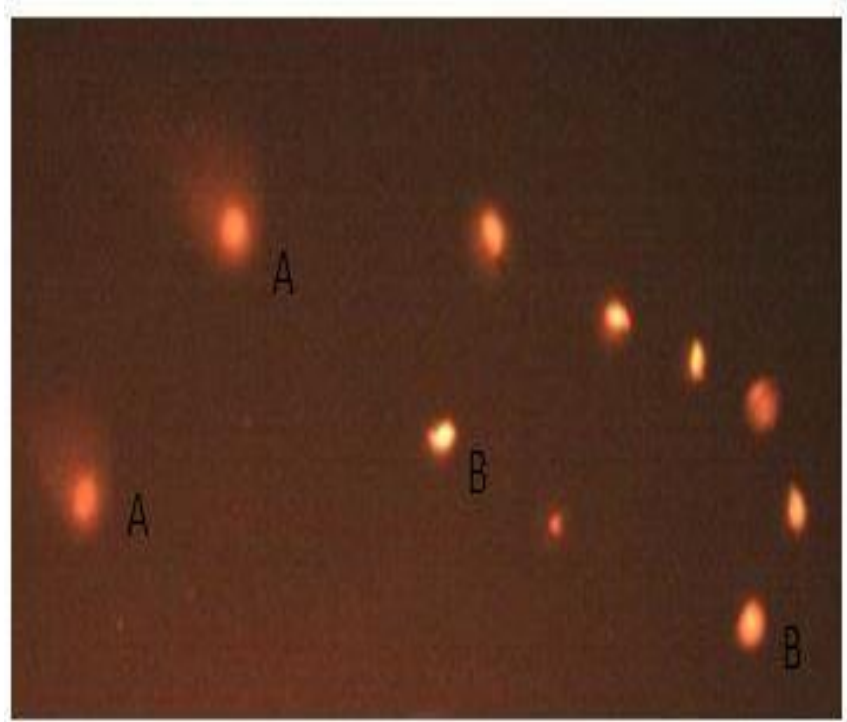

Fig.1: Comet picture of buffalo spermatozoa cryopreserved in Tris diluent containing a mixture of $\mathrm{G}+\mathrm{DMSO}+$ duck egg yolk with (A) or without (B) no DNA fragmentation.

\section{DISCISSION}

In the current study combinations of penetrative cryoprotectants including glycerol, DMSO and DMF with two egg yolk sources (CEY \& DEY) were evaluated aiming to improve the quality of frozen-thawed buffalo-bull spermatozoa. Our results revealed that buffalo spermatozoa were better cryopreserved using 7\% glycerol as CPA rather than using the same concentration of DMF and DMSO in terms of post-thaw motility and DNA, membrane and acrosomal integrities. Similarly, many researchers considered glycerol (at 6 to $7 \%$ concentration) to be the most suitable CPA for buffalo semen cryopreservation (Rasul et al., 2007; Sianturi et al., 2012; Shahverdi et al., 2014; Kumar et al., 2016; Herbowo et al., 2019). Generally, the glycerol is being routinely used as a major cryoprotectant for mammalian sperm freezing (García et al., 2012) due to its slow permeability across the plasma membrane (Gao and Critser, 2000; García et al., 2012; Vafaei et al., 2019).

In a recent study, glycerol was found to improve the post-thaw buffalo sperm characteristics including motility, viability, plasma membrane integrity, acrosomal membrane integrity as well as yielded higher pregnancy rate in comparison with EG and DMSO (Almadaly et al., 2019). Furthermore, Tasdemir et al. (2013) reported that there was no advantage in using EG or DMSO for freezing of buffalo spermatozoa as $\mathrm{G}$ yielded better post-thaw sperm characteristics as compared to EG and DMSO.

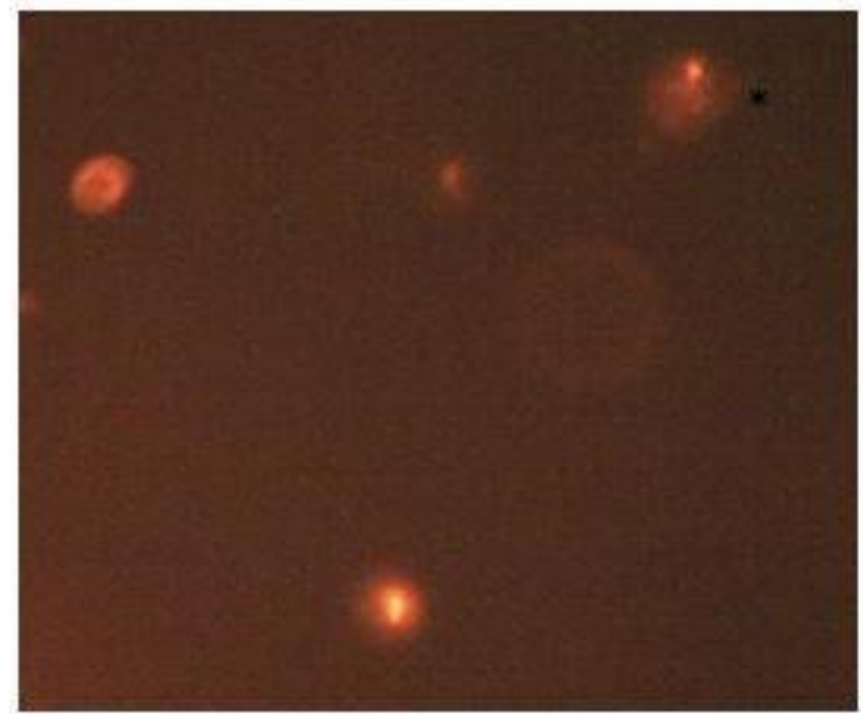

Fig.2: Comet picture of buffalo spermatozoa cryopreserved in Tris diluent supplemented with DMF and chicken egg yolk showing DNA fragmentation (Asterix).

Also, Guerrero (2006) found that the post-thaw motility and membrane intactness of bull spermatozoa frozen in 7\% G-Tris-based extender were significantly higher than those of sperm frozen in 7\% EG-Tris-based extender. In bovines, El-Harairy et al. (2011) found that post-thaw motility and the conception rate of bull spermatozoa frozen in a lactose-yolk-citrate extender containing $7 \% \mathrm{G}$ or $7 \%$ DMSO was similar. On the contrary to our results, Swelum et al. (2011) reported that 5\% EG resulted in greater post-thaw intactacrosome, intact-plasma membrane and conception rate of buffalo-bull spermatozoa than $7 \%$ G. This discrepancy might be due to different animal breed and semen extender as well as diverse cooling and freezing protocols.

There were marked species differences in the effect of DMF on sperm freezability. The use of DMF improved cryo survival of frozen-thawed semen in equine (Ghallab et al., 2019), caprine (Ariantie $\boldsymbol{e t}$ al. 2013), and swine (Bianchi et al. 2008); however, DMF is not an effective cryoprotectant for ram (Moustacas et al., 2011) canine (Mota-Filho et al. 2011) sperm. The differences in the composition of sperm membrane among species are more likely to be the reason for the different results. Mota-Filho et al. (2011) attributed the sperm intolerance to DMF to either biochemical effects or due to osmotic imbalance. 
Permeable cryoprotectants including glycerol, DMSO and DMF pass through the plasma membrane and replace the water in the sperm cell (Di Santo et al., 2012). Such cryoprotectants are toxic at higher concentrations and numerous reports have shown that sperm fertility potential is dramatically decreased in freezing medium supplemented with high concentrations of these permeable agents (Gilmore $\boldsymbol{e t}$ al., 1997). So, the use of two permeable cryoprotectants rather than a single one is recommended to enables the use of lower concentrations of each cryoprotectant, thereby reducing potential toxicity (Pugh et al., 2000). In the present study DNA integrity was better maintained by the use of a combination of G + DMSO. DNA integrity is a concern during cell freezing because cryopreservation easily changes mitochondrial membrane properties and increases the production of ROS (Reactive Oxygen Species), which may subsequently result in the oxidation of DNA, producing high frequencies of single and double-strand DNA breaks (Said et al., 2010).

Currently, egg yolk is a common component of most semen extenders for domestic animals as it protects the plasma membrane and acrosome against temperature-related injury (Amirat et al., 2004). Chicken EY is the most commonly used EY because of its easy availability (Bathgate $\boldsymbol{e t}$ al., 2006). However, the extenders containing EYs from the avian species other than chickens resulted in significantly high postthawing parameters in buffalo sperm (Andrabi et al., 2008; Waheed et al., 2012; Akhter et al., 2017), bulls (Su et al., 2008), equine (Webb et al., 2011), and rams (Ali et al., 2013). It is suggested that this improvement in post-thaw sperm quality is attributed to the differences in the biochemical composition of the yolks. Our finding that the cryo survival of buffalo spermatozoa is more improved by adding DEY rather than CEY came in accordance with those recorded in buffalo by Waheed et al. (2012) and El-Sharawy et al. (2015) in buffalo bulls. According to Bathgate et al. (2006), the basic components of CEY and DEY did not differ, but the ratios of fatty acids and phospholipid were different. The yolk from duck eggs had more monounsaturated fatty acids than yolk from chicken eggs. Moreover, yolk from duck eggs contained more phosphatidylinositol than CEY.

\section{CONCLUSIONS}

It is suggested that the interaction between permeating and nonpermeating CPAs had improved most of the post-thaw sperm parameters studied herein and it may be related to the possible synergism among these compounds. So, it could be concluded that Tris extender containing a mixture of $3.5 \%$ glycerol $+3.5 \%$ DMSO with duck's egg yolk is recommended as it enhances post-thaw motility and functional integrity of cryopreserved buffalo spermatozoa

\section{REFERENCES}

AKHTER, S., RAKHA, B., ANSARI, M., HUSNA, A., IQBAL, S., AND KHALID, M. 2017. Evaluation of quail and turkey egg yolk for cryopreservation of NiliRavi buffalo bull semen. Theriogenology 87: 259-265.

ALI, ABT, BOMBOI, G., AND FLORIS, B. 2013. Replacing chicken yolk with yolks from other sources in ram semen diluents and their effects on fertility in vitro. Small Rum. Res. 113: 405-410.

AKHTER, S., ANSARI, MS, RAKHA, BA, ANDRABI, SMH, KHALID, M. AND ULLAH, N. 2011. Effect of low-density lipoproteins in extender on freezability and fertility of buffalo (Bubalus bubalis) bull semen. Theriogenology 76:759-764.

ALMADALY, EA, TAWFIK, FS, EL-KON, II, HELEIL, BA, AND FATTOUH, EM 2019. Effect of different cryoprotectants on the post-thaw sperm characteristics and in vivo fertility of buffalo (Bubalus bubalis) bull semen. Slov. Vet. Res. 56: 541-551

AMIRAT, L., TAINTURIER, D., JEANNEAU, L., THORIN, C., GÉRARD, O., COURTENS, JL, AND ANTON, M., 2004. Bull semen in vitro fertility after cryopreservation using egg yolk LDL: a comparison with Optidyl®, a commercial egg yolk extender. Theriogenology 61: 895-907.

ANDRABI, S., ANSARI, M., ULLAH, N., ANWAR, M., MEHMOOD, A., AND AKHTER, S. 2008. Duck egg yolk in extender improves the freezability of buffalo bull spermatozoa. Animal Reprod. Sci. 104: 427-433.

ARIANTIE, OS, YUSUF, TL, SAJUTHI, D., AND ARIFIANTINI, RI, 2013. Effect of glycerol and dimethylformamide cryoprotectants on buck Etawah Crossbreed frozen semen using modified tris Diluents. JITV. 18: 239-250.

BADR, MR, ABD EL-MALAK, MG, AND HASSAN, HM, 2010. Effect of trehalose on cryopreservation, oxidative stress and DNA integrity of buffalo spermatozoa. J Reprod. Infertil. 1:50-57.

BAREN, A., BACINOGLU, S., EVECEN, M., SAHIN, BE, ALKAN, S., DEMIR, K., AK, K., AND ILERI, K. 2004. Freezing of cat semen in straws with different GLY levels containing Tris-extender. Turk. J. Vet. Anim. Sci., 28: 545-552.

BATHGATe, R., MAXWELl, W., AND EVANS, G. 2006. Studies on the Effect of Supplementing Boar Semen Cryopreservation Media with Different Avian Egg Yolk Types on in Vitro Post-thaw Sperm Quality. Reprod. Dom. Anim. 41: 68-73.

BIANCHI, I., CALDERAM, K., MASCHIO, EF, MADEIRA, EM, DA ROSA ULGUIM, R., CORCINI, CD, BONGALHARDO, DC, CORREA, EK, LUCIA JR, T., DESCHAMPS, JC, AND CORREA, MN 2008. Evaluation of amides and centrifugation temperature in boar semen cryopreservation. Theriogenology 69: 632-638. 
BUCAK, MN, AND UYSAL, O., 2008. The role of antioxidants in freezing of Saanen goat semen. Indian Vet. J. 85: 148-150.

DIDION, BA, DOBRINSKY, JR, GILES, JR, AND GRAVES, CN, 1989. Staining procedure to detect viability and true acrosome reaction in spermatozoa of various species. Gamete Res. 22: 51-57.

DI SANTO, M., TAROZZI, N., NADALINIW, M., AND BORINI, A. 2012. Human sperm cryopreservation: Update on techniques, effect on DNA integrity, and implications for art. Adv. Urol. 2012: 854837 (12 pages).

EL-BADRY, DA, ABEER M. ANWER, AND RAWASH, ZM 2014. Effect of different concentrations of sodium dodecyl sulfate, egg yolk and glycerol on the freezability and DNA integrity of Arabian stallion spermatozoa. Assiut Vet. Med. J. 60:29-37.

EL-HARAIRY, MA, EID, LN, ZEIDAN, AEB, ABD ELSALAAM, A.M., EL-KISHK, AND MAM 2011. Quality and fertility of the frozen-thawed bull semen as affected by the different cryoprotectants and glutathione levels. J. Am. Sci. 7: 791-801.

EL-SHARAWY, ME, EL-SEIFY, EM HUSSIEN, A.M., EL-SHERBIENY, M., EL-AND SHAMAA, IS 2015. Effect of Duck Egg Yolk on Cryopreservation and Fertility of Egyptian Buffalo Bull Semen. International J. Agri. Innovations \& Res. 3:2319-2437.

FRASER, L., 2004. Structural damage to nuclear DNA in mammalian spermatozoa: its evaluation techniques and relationship with male infertility. Polish J. Vet. Sci. 7: 311-321.

GAO, D., AND CRITSER, JK, 2000. Mechanisms of Cryoinjury In Living Cells. Ilar, J. 41: 187-196.

GARCÍA，BM，FERRUSOLA，CO，APARICIO, IM, MIRO-MORAN, A., RODRIGUEZ, A.M., BOLAOS, JG, FERNANDEZ, LG, DA SILVA, CB, MARTINEZ, HR, TAPIA, JA, AND PENA, FJ 2012. Toxicity of glycerol for the stallion spermatozoa: effects on membrane integrity and cytoskeleton, lipid peroxidation and mitochondrial membrane potential. Theriogenology 77:1280-1289.

GHALLAB, A.M., ABOU-AHMED, MM, FADL, A.M., EL-BADRY, DA, SHAHAT, A.M., AND MOAWAD, AR 2019. Optimization of the protocol for cryopreservation of Arabian stallion spermatozoa: effects of centrifugation, semen extenders and cryoprotectants. CryoLetters 40: 129-138.

GILMORE, J., LIU, J., GAO, D., AND CRITSER, J. 1997. Determination of optimal cryoprotectants and procedures for their addition and removal from human spermatozoa. Hum. Reprod. 12: 112-118.

GUERRERO, CA, 2006. Cryopreservation and intracytoplasmic sperm injection with bovine epididymal spermatozoa ( $\mathrm{PhD}$ Thesis). Fac Agric and Mechanical College, Louisiana State University; Mexico.

HAMMERSTEDT, RH, GRAHAM, JK, AND NOLAN, JP, 1990. Cryopreservation of mammalian sperm: what we ask them to survive. J. Androl. 11: 73-88.

HERBOWO, MT, ARIFIANTINI, RI, KARJA, NWK, AND SIANTURI, RG 2019. Cryopreservation of Swamp Buffalo Semen in Skim Milk Yolk-based
Diluent with Two Different Cryoprotectants. Tropical An.al Sci. J. 42(1):13-18.

HUGHES, CM, LEWIS, SE, MCKELVEY-MARTIN, V., AND THOMPSON, WA, 1996. Comparison of baseline and induced DNA damage in human spermatozoa from fertile and infertile men, using a modified comet assay. Mol. Hum. Reprod. 2: 613-619.

HU, JH, LI, QW, ZAN, LS, JIANG, ZL, AN, JH, AND WANG, LQ. 2010. The cryoprotective effect of lowdensity lipoproteins in extenders on bull spermatozoa following freezing-thawing. Anim. Reprod. Sci. 117:11-17.

JEYENDRAN, R. S., VANDER-VEN, HH, PEREZPELAEZ, M., CRABO, BG, AND ZANEVLD, LJD, 1984. Development of an assay to assess the functional integrity of the human sperm membrane and its relationship to other semen characters. J. Reprod. Fertil. 70: 219-228.

KHALIFA, TAA, 2001. Effect of some antioxidants on the viability of preserved buffalo and ram semen. $\mathrm{PhD}$ Thesis, Fac. Vet. Med. Cairo Univ.

KUMAR, D., KUMAR, P., SINGH, P., YADAV, SP, AND YADAV, PS 2016. Assessment of sperm damages during different stages of cryopreservation in water buffalo by fluorescent probes. Cytotechnology 68: 451-458.

LEBOEUF, B., RESTALL, B., AND SALAMON, S. 2000. Production and storage of goat semen for artificial insemination. Anim. Reprod. Sci. 62: 113141.

LEI, SU, XILONG, LI, JIEXIAQUAN, SY, YAHUI, LI, XIECHAO, HEX, AND IANGHUI, T. 2007. A comparison of the protective action of added egg yolks from five avian species to the cryopreservation of bull sperm Anim. Reprod. Sci. 104: 212-219.

MILOVANOV, VK 1962. Biology of Reproduction and Artificial Insemination of Farm Animals. Monograph. Selkohz. Lit. J. and Plakatov, Moscow.

MOFFET, PD, BRUEMMER, JE, CARD, C., AND SQUIRES, E.L. 2003. Comparison of dimethylformamide and glycerol for cryopreservation of equine spermatozoa. In: Proceedings Society for Theriogenology Annual Conference, 2003, Columbus, OH. Montgomery, AL: pp. 42 (abst.).

MOTA-FILHO, AC, TELES, CHA, JUCA, RP, CARDOSO, JFS, UCHOA, DC CAMPELLO, CC, SILVA, AR, AND SILVA, LDM 2011. Dimethylformamide as a cryoprotectant for canine semen diluted and frozen in ACP-106C. Theriogenology 76:1367-1372.

MOUSTACAS, VS, CRUZ, BC, VARAGO, FC, MIRANDA, DA, LAGE, PG, AND HENRY. M. 2011. Extenders containing dimethylformamide associated or not with glycerol are ineffective for ovine sperm cryopreservation. Reprod. Dom. Anim. 46:924925.

PUGH, PA, TERVIT, HR, AND NIEMANN, H. 2000. Effects of vitrification medium composition on the survival of bovine in vitro produced embryos, following in straw-dilution, in vitro and in vivo following transfer. Anim. Reprod. Sci. 58: 9-22.

PURDY, PH 2006. A review: on goat sperm cryopreservation, Small Rum. Res. 63: 215-222. 
RASUL, Z., AHMED, N., AND ANZAR. M. 2007. Antagonist effect of DMSO on the cryoprotection ability of glycerol during cryopreservation of buffalo sperm. Theriogenology 68:813-819.

REDDY, NSS, MOHANARAO, GJ AND ATREJA, SK 2010. Effects of adding taurine and trehalose to a trisbased egg yolk extender on buffalo (Bubalus bubalis) sperm quality following cryopreservation. Anim. Reprod. Sci. 119: 183-190.

ROHILLA, RK, TULI, RK, AND GOYAL, RL 2005. Comparative study of the effects of cryoprotective agents in freezing Murrah buffalo bull semen. Ind. J. Vet. Res. 14: 37-43.

ROYERE, D., BARTHELEMY, C., HAMAMAH, S., AND LANSAC, J. 1996. Cryopreservation of spermatozoa: A review. Hum. Reprod. 2: 553-559.

SAID, TM, GAGLANI, A., AND AGARWAL, A. 2010. Implication of apoptosis in sperm cryoinjury. Reprod. Biomed. 21: 456-462.

SHAHVERDI, A., RASTEGARNIA, A., AND TOPRAGGALEH, TR 2014. Effect of extender and equilibration time on post-thaw motility and chromatin structure of buffalo (Bubalus bubalis) bull spermatozoa. J. Cell 16: 279-288.

SIANTURI, RG, PURWANTARA, B., SUPRIATNA, I., AMROZI, I., AND SITUMORANG, P. 2012. Effect of glutathione and bovine seminal plasma in lactose extender on viability of swamp buffalo frozen semen. JITV. 17: 169-178.

SNEDECOR, GW, AND COCHRAN, WG 1989. Statistical Methods. $8^{\text {th }}$ Ed. Iowa State Univ. Press, Ames, IA, USA.

SU, L., Li, X., QUAN, J., YANG, S., LI, Y., HE, X., AND TANG, X. 2008. A comparison of the protective action of added egg yolks from five avian species to the cryopreservation of bull sperm. Anim. Reprod. Sci. 104: 212-219.

SWELUM, AA, MANSOUR, HA, ELSAYED, AA, AND AMER, AH 2011. Comparing ethylene glycol with glycerol for cryopreservation of buffalo bull semen in egg-yolk containing extenders. Theriogenology 76: 833-842.

TASDEMIR, U., BUYUKLEBLEBICI, S., TUNCER, PB, COSKUN, E., OZGURTAS, T., AYDIN, FN,
BUYUKLEBLEBICI, O., AND GURCAN, IS 2013. Effects of various cryoprotectants on bull sperm quality, DNA integrity and oxidative stress parameters. Cryobiology 66: 38-42.

VAFAEI, F., KOHRAM, H., ZAREH-SHAHNE, A. AHMAD, E., AND SEIFI-JAMADI, A. 2019. Influence of Different Combinations of Permeable and Non-permeable Cryoprotectants on the Freezing Capacity of Equine Sperm. J. Equine Vet. Sci. 75: 69.

VIDAMENT. M. 2005. French field results (1985-2005) on factors affecting fertility of frozen stallion semen. Anim. Reprod. Sci. 89:115-134.

WAHEED, S., AHMAD, N., JAMIL-UR-RAHMAN, H., YOUNIS, M., AND IQBAL, S. 2012. Evaluation of duck egg yolk for the cryopreservation of Nili-Ravi buffalo bull semen. Anim. Reprod. Sci. 131: 95-99.

WEBB, GW, BURRIS, CL, HARMON, SE, AND BAKER, RH, 2011. Effects of egg yolk source on the cryopreservation of stallion spermatozoa. J. Equine Vet. Sci. 31: 166-173.

WUNDRICH, K., PAASCH, U., LEICHT, M., AND GLANDER, HJ 2006. Activation of caspases in human spermatozoa during cryopreservation - an immunoblot study. Cell Tissue Bank, 7: 81-90.

How to cite this article:

Rawash, Z.M.; Amal Z. Leil Abeer M. Anwer, and El-Badry, D.A. 2020. Influence of Combinations of Some Permeable Cryoprotectants With Chicken And Duck Egg Yolks on Freezability and DNA Integrity of Buffalo Spermatozoa.Journal of Applied Veterinary Sciences, 5(3): 49 - 56.

DOI: HTTPS://DX.DOI.ORG/10.21608/JAVS.2020.98371 